\title{
THE COMPARATIVE STUDY OF LAW FOR POLICY PURPOSES: VALUE CLARIFICATION AS AN INSTRUMENT OF DEMOCRATIC WORLD ORDER*
}

\author{
By MYRES S. MEDOUGAL广
}

\begin{abstract}
"[E]very true science employs a method of which the technical and proiessional schools make little use. This method is comparison. It is preeminently the scientific method; without the employment of the comparative method, no body of knowledge regarding the facts of social life can take rank as a science."

Smith, A General View of European Legal History and Other Papers 263 (1927).

"The method of natural science rests always on the comparison of observed phenomena, and the aim of such comparison is by a careful examination of diversities to discover underlying uniformities. Applied to human societies the comparative method used as an instrument for inductive inference will enable us to discover the universal, essential, characters which belong to all human sacieties, past, present, and future. The progressive achievement of knowledge of this lind must be the aim of all who believe that a veritable science of human society is possible and desirable."

Radcliffe-Brown, Preface in Fortes \& Evans-Pritchard, African Political Systens xi (1940).
\end{abstract}

IN a world shrinking at an ever accelerating rate because of a relentlessly expanding, uniformity-imposing technology, both opportunity and need for the comparative study of law are unprecedented. In this contemporary world, people are increasingly demanding common values that transcend the boundaries of nation-states; they are increasingly interdependent in fact, irrespective of nation-state boundaries, for controlling the conditions which affect the securing of their values; and they are becoming ever more realistic in their consciousness of such interdependences, and hence widening their identifications to include in their demands more and more of their fellow men. ${ }^{1}$ These changing perspectives of peoples the world over stimulate in turn ever intensifying demands for wider and wider political cooperation, for the more and more effective use of conjoined community power, in order to secure newly clarified and established goals. A general purpose world organization, a host of ancillary and subsidiary organizations and agencies, a great range of regional pacts and understandings and of functional unifications, and multi-

*This article was prepared for the inaugural issue of the Arsegress Jourwar or Conparative Law, of which the Yale Law School is a co-sponsor. The Editors of the YALE LAw JouRNAL present this article through the courtesy of the new Journal.

$\div$ William K. Townsend Professor of Law, Yale Law School.

1. Wright, The World Comarunity (1948); Lasswell, The World Rerolumo: of ouR TIMIE (1951) and The Interrelations of World Organization and Sociely, 55 Yare L. J. SS9 (1946), reprinted in Lerner \& Lassweli, The Policy Scievices c. VI (1951); Ogburn, Technology and International Relations (1949); New Cospass of the WORLd (Weigert, Stefansson, Harrison eds. 1949); MIOST OF THE WOrLd (Linton ed. 1949). 
plied thousands of multilateral and bilateral agreements all bear witness, and the beginning only is here. ${ }^{2}$ The values for which this cooperation is demanded embrace the whole of our present-day democratic preferences for a peaceful world. Such values include not only security, in the sense of full opportunity, free from violence and threats of violence, to pursue all values by peaceful, non-coercive procedures, but also all the other value-variables upon which such security depends: ${ }^{3}$

the wide sharing of power, both formal and effective, including participation in the processes of government and of parties and pressure groups, and equality before the law;

freedom of inquiry and opinion and for communication of the $\mathrm{cm}$ lightennent by which rational decisions can be made;

the access to resources and technology necessary to the production of goods and services for maintenance of rising standards of living and comfort;

2. Sohn, Cases and Other materials on World Law (1950); De Russet, Strengthening the Frasework of Peace (1950); Levi, Fundamentals of World Organization (1950); Holborn, The Political Collayse of Europe (1951). Bewr, Regional Organizations: Their Functions and Potentialities in the World ComMrUNity (unpublished J.S.D. thesis in Yale Law School Library, 1951).

3. The itemization that follows is one designed to permit, by the use of appropriate operational indices, the most detailed comparative description of varying legal doctrines and practices, and will be employed in later sections of this article. The reference to "value-variables" is intended to emphasize that each value may in varying contexts be both a value that is demanded and a base of power for affecting the distribution of values. For more detailed statement of the type of analysis proposed, see Lasswell \& McDougal, Legal Education and Public Policy: Professional Training in the Public Interest, 52 Yale L. J. 203 (1943); Lasswell \& Kaplan, Power and Socjery (1950); McDougal \& Leighton, The Rights of Man in the World Community: Constitutional Illusions Versus Rational Action, 59 Yale L. J. 60 (1949); The Policy Sciences (Lerner \& Lasswell eds. 1951).

We emphasize "policy purposes" because we regard a jurisprudence which purports to be "scientific" only as inadequate. As important as it is for an observer not to permit his preferences to distort his vision of the events being observed, a creative jurisprudence requires not only the ways of thinking and procedures of observation commonly called scientific but also a number of other integrated and interrelated methods of thought and observation. Such other methods include the clarification of goal values, the description of historical and contemporary trends in the realization of values, the critical projection of trends into the future on the basis of historical and scientific knowledge, and the illvention and evaluation of alternatives of policy by which fundamental goal values can be most fully attained. The use of scientific procedures alone may, as many studies have demonstrated, be utterly haphazard and sterile. The other modes of thinking and obscrvation are required to guide the use of scientific procedures to important problems, to determine the degree of quantification or mathematicization necessary in any particular investigation, and to process any knowledge acquired for use by decision-makers. Effective inquiry into law requires emphasis upon both policy and science-in sum, a disciplined use of all relevant modes of thinking and observation. 
the fundamental respect for human dignity which both precludes discrimination based on race, sex, color, religion, political opinion, or other ground irrelevant to capacity and provides a positive recognition of common merit as a human being and special merit as an individual;

health and well-being and inviolability of the person, with freedom from criel and inhuman punishments and positive opportunity for the development of talents and enrichment of personality;

opportunity for the acquisition of the skill necessary to express talent and to achieve individual and community values to the fullest;

opportunity for affection. fraternity, and congenial personal relationships in groups freely chosen;

and, finally, freedom to justify common standards of responsibility and rectitude, to explain life, the universe, and values, and to worship God or gods as may seem best.

It needs no new emphasis that our contemporary demands for cooperation that transcends nation-state boundaries in the shaping and sharing of values occur in the context of a world power process. In this process the policies that determine the degree to which we can achieve our values are formulated by many participants - conveniently categorized as nation-states, international governmental organizations, political parties, pressure groups, private associations, and individual human beings-in multitudinous interactions, the ramifications and effects of which are global in their reach. The practices by which any one participant engages in this process, the bases of its power, and the area, scope, and weight of influence it achieves are obviously directly affected by the practices, bases of power, and effects achieved by each of the other participants. ${ }^{5}$ Thus, how a nation-state controls its people and resources and organizes its institutions as bases of power, how it structures and operates its foreign affairs procedures for peace and war, and how it regulates and controls or supports and exports political parties, pressure groups, and private associations, may vitally affect the general practices of other nation-states and their willingness or unwillingness to engage in particular measures of cooperation. Such practices may also affect the amount of power that can be conferred upon international governmental organizations and the trans-national roles that can be permitted to parties, pressure groups, private associations, and individual human beings. It is, therefore, an opportunity of overwhelming urgency for the comparative study of law to explore the power processes of the nation-states of the world and to clarify the variables, both predispositional and environmental, which move different decision-makers in different nationstates. The urgency of this opportunity is no less whether one's expectations

4. Schwarzengerger, Power Polmitcs (2d. rev. ed. 1951); Spykuraj, The Geocraphy of the Peace (1944).

5. For development see MeDougal, The Role of Law in World Politics, 20 Miss. L. J. 253 (1949) and Law and Power, 46 Axs. J. INT'L. L. 102 (1952). 
are of future peace or of imminent world-wide violence or whether one envisages the whole globe as the area of cooperation or only certain accessible portions of the globe. ${ }^{6}$ The need is for that understanding of the power processes of ourselves and others which can give us both realistic orientation in the world power process as a whole and the special insight required for effective cooperation in the promotion of each of our basic democratic valtues, whatever the exigencies of future violence and whatever the area in which we can work. ${ }^{7}$

It may be questioned, however, whether our traditional conceptions and techniques of comparative study are adequate to meet such contemporary need. Despite many exhortations over a period of years, ${ }^{8}$ contributions important to understanding and cooperation are relatively few and little important work is presently being done in our law schools or elsewhere. ${ }^{0}$ Almost any sampling of current literature and comment reveals sharp discontent with the effects

6. See Loewenstein, Stoke \& Cole, The Role of Comparalive Govermment in Researce In Political Sctence 17 (Griffith ed. 1948): "In this period of total war, which has added to belligerency of a military, economic, and diplomatic character political warfare as a way to victory, the knowledge of foreign political institutions and ideologies has become of paramount importance. Cooperative government has been transformud from a Cinderella-like academic discipline into a political instrumentality of the most immediate potency. It is obvious that without intimate knowledge of their political institutions and attitudes we could not hope to understand what makes our enemies strong, or to pierce their psychological armor; nor would we be able to assist them after the war in reintegration into the world community, in case this should be our task."

7. Cf. Yntema: Comparative Research and Unification of Laze, $41 \mathrm{MrcH}$ L. Rev. 261 (1942); Research in Inter-American Law at the University of Michigan, 43 Micil. L. Rev. 549 (1944); and Book Review, 54 YALE L. J. 889 (1945); Hazard, Comparative Law in Legal Education, 18 U. of CHI. L. Rev. 264 (1951); F. Stone, The End to be Served by Comparative Laze, 25 Tulane L. Rev. 325 (1951); I Raber, The Conflict of Laws: A Comparative Study xii (1945); David, Traite Ellunentaire de Drout Civil Compare 1-214 (1950); Czyzak, Book Review, 1950 Wash. U.L.Q. 548; and Kuhn, The Function of the Comparative Method in Legal History and Philosophy, 13 Tunant L. Rev. 350 (1939).

8. One of the most useful articles still is Lepaulle, The Function of Comparative Law, 35 Harv. L. Rev. 838, 857, 858 (1922). M. Lepaulle urged: "But in a period like the present, when many social organisms and functions are growing very rapidly, often in unforeseeable ways, when the law, in many points, is already far behind the times, when there is a rising discontent with the inadequacy of the law to meet the new condltions, it seems that the first duty of any law school, either toward the science of law at large, or toward its own country, is to train the new generation in such a way as to enable it to meet the entirely new situations created by the new and profound changes in modern society."

9. Note the relative paucity of studies cited in Schlesinger, Comparatrve. Law Cases and Materials 144 (1950).

It is not intended by this over-all negative appraisal to underestimate the importance of certain specific contributions, such as those of Professor Rabel in Privatc lntcrnationtal Law or of Professor Hazard in Russian Law. Such oases serve, however, only to make more conspicuous the desert. 
being achieved. ${ }^{10}$ In typical summary Dean Wigmore some twenty years ago characterized the "literature of comparative law" as being "marked frequently" by the barren dissection of verbal tests"11 and most recently Professor Von Mehren in singling out one book for especial praise, offers contrast with "the glib, overly general and painfully superficial treatments which have so often passed current as comparative law."12

The causes of the failure of comparative study to rise to contemporary need are of course various. Some observers have stressed lingering isolationism ${ }^{13}$ and narrow, ill-conceived vocationalism. ${ }^{11}$ MIost fundamental, however, is the general failure of legal scholarship to invent and employ a method adequate to the task of realistically describing and effectively appraising a flow of authoritative decisions through time, i.c., for malking fruitful comparisons through time, whether the comparisons are confined to decisions within the boundaries of a single nation-state or extended across boundaries. ${ }^{15}$

The greatest confusion continues to prevail about what is being compared, about the purposes of comparison, and about appropriate techniques. The "law" that is being studied is still too often regarded as a body of doctrine or rules, divorced from power and social processes. Studies are still organized, and comparisons attempted, in terms of technical doctrines of highest level

10. Thus Stone, supra note 7, at 334, writes: "Perhaps at no time in history have we had so many conferences, so many books and exchanges and yet so little clear linowledge of the end which they serve."

For a sampling of book reviews highly critical of present methods and results, see Riesenfeld, 3 J. LEGAL Ed. 620 (1951) ; Fulda, 36 Corx. L. Q. 185 (1950) ; F. Stone, $2 j$ N.Y.U.L.Q. Rev. 239 (1951); Timasheff, id. at 393. And see Rashba, Consecrated Ignorance of Foreign Law?, 39 CALIF. L. REv. 355 (1951).

11. Wigmore, More Jottings on Comparatize Legal Idcas and Inslitulions, 6 TuLAre L. REv. 244, 263 (1932).

12. Von Mehren, Book Review, 65 Harv. L. Rev. 532, 534 (1952). The hook praised is Dawson, Unjust Enrichusent: A Cosparatrve Axulysis (1951).

13. Macmillan, Book Review, 63 L. Q. KEv. 227, 228 (1947) writes: "Isolationism may well find its last refuge in the tenacity with which each nation clings to its own legal system."

14. F. Stone, Book Review, 26 N.Y.U.L.Q. 239 (1951).

See Yntema, Research in Inter-American Law at the Unizersity of Micligan, 43 MicF. L. REv. 549, 550 (1941): "Thus, until but recently, historical attachment to the Common Law as a bond of Anglo-Saxon unity, acceptance of the formal, authoritarian notion of law developed by Austin as the instrument of utilitarian reform, and the approach to government as a branch of social science, the last outside the pale of law proper, incongruously joined to form a basic philosophy of law in the United States, that while it persisted, doomed legal science to exegetic impotence."

15. Intema has made the point most cogently that fruitful historieal study of decisionmaking processes within a single nation-state requires perfection and application of comparative methods. See Roman Law as the Basis of Comparatize Law, in 2 Lnw: A Centuty of PrCGRess 346 (1937) and Rescarch in Inter-American Lani at the Cratersily of Michigan, 43 MICe. L. REv. 549 (1944). Cf. Pollock, The History of Comparatice

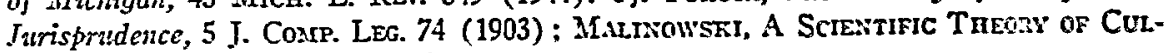
tore ANd OTher Essays (1944). 
ambiguity, doctrines which purport to perform in one and the same reference the very different functions of describing past decisions, prescribing what future decisions should be and predicting such decisions. The conception of law as a decision-making process, and a process in which the decisionmakers are influenced by many variables, has had as yet but few effects. Conceptions of scientific method for study of the variables, including technical doctrines, that affect decisions are most inadequate. Precise study of trends in decision and conditioning factors is almost non-existent. Little effective effort is made to relate decisions to basic community values or, when discrepancies are observed, to clarify values and adopt a creative attitude in the invention and adaptation of new means. The consequence is a literature that is voluminous, obsessively repetitious, and sterile-a literature that feeds and grows, like a psychic cancer, upon logical classification and reclassification and technical refinement and sub-refinement, without limit and with a minimum of external reference and relevance. ${ }^{10}$

Remedy for the failure of comparative study must naturally begin with the removal of its causes. Any program for the comparative study of law which would be fruitful must, therefore, include among its intellectual tools three indispensable prerequisites : first, a clear and realistic notion of what is being compared; second, an understanding of and interest in the purposes of the comparison sufficient to guide and sustain it; and, finally, techniques of comparison adequate to yield knowledge relevant to and sufficiently precise for the purposes established. ${ }^{17}$ It is to each of these prerequisites that we propose to direct a few preliminary and tentative observations. ${ }^{18}$

It is fortunately becoming increasingly recognized that what must be compared, if comparisons are to be relevant and useful, is not doctrine merely

16. Hug \& Ireland, The Progress of Comparative Laze, 6 TuLANe L. REv. 68, 73 (1931) excoriate common procedures: "To take some rule or accepted formula covering a definite point of doctrine in one system of law, find a similar expression in one or more -other systems, and write a note or longer comment which could in effect be boiled down to a quotation of the various provisions more or less adequately translated into the author's language with references (as to the variously numbered sections of the respective national codes) sufficient to enable the original versions to be found, neither involves important mental processes by the writer nor excites contributory stimulation in the reader. A numerically selective robot could produce as fruitful results from a good shelf of statutory compilations. It may be remarked in passing that the character, as secondary source material, of any discussion of one or more problems in the system of law of a single jurisdiction or of the whole system itself (however exotic and remote ethnically or gcographically) or of a single homogeneous group (as the civil law), is not altered by its being presented in a language or place not its own; and such a presentation does not by itsclf fall within our definition of comparative law."

17. Schmitthoff, The Science of Comparative Law, 7 CaMb. L. J. 95 (1939) makes comparable demands and offers the beginnings of clarity in establishing an adequate theoretical structure.

18. Throughout this article the writer draws heavily upon collaborative studies with Professor Harold Lasswell in seminars on Law, Science, and Policy and World Community and Law. 
but doctrine and practice, not a flow of rules merely, but a flow of decisions. ${ }^{10}$ Comparison cannot relevantly and usefully be confined to rules alone both because rules are not the only variables that affect decision and because, as embodiments of policy crystallizations of the past, they may not offer adequate description of the effects of new decisions. ${ }^{20}$ The process of decision-making is, indeed, one of continual redefinition of doctrine in the formation and application of policy to ever-changing facts in ever-changing contexts. ${ }^{21}$ The variables to which decision-makers respond, the factors which affect decision, are both environmental and predispositional. Environmental variables include

19. For inspiring application of this insight see Llewewrys \& Hozke, TkE Cheyenne Way (1941).

In The Progress of Comparatic'e Lana', 6 Turane L. Rex. 68, 73 (1931), Hug and Ireland make eloquent statement: "To understand the history of the rule, to trace its principal sources, its developing vicissitudes, and its final formation and acceptance, to appreciate its relation to other parts of the instant system, and, most important of all, to learn its actual operation, to see what it does as distinct from what it says, by consultation of the commentators and more importantly by examination of the actual decisions of the courts, to carry through this analysis for each of the great systems of law, classifying and discussing as many of the subdivisions as circumstances permit, to discover and set forth the similarities and differences of the existing solutions, and then to malie a summation of the whole resultant with a view to an at least partial and temporarily valid prediction as to the tendency of current doctrine and lines of decision, more correctly constitutes the real purpose of comparative law."

In Research in Inter-American Law' at the Unizersity of Michigan, 43 MIICn. L. REv. 549,557 (1944), Yntema insists: "Mere formal collocation of the laws to be compared is not adequate; account must be taken of the interpretative doctrines and their illuminating applications by the courts to specific problems, as well as of the differing structures of ideas, the historical background, and the special procedural and practical aspects, relating to each question. The problem is to examine not mere formulations in abstract but functioning legal institutions, as they appear each in its more or less specifie social context."

20. Kahn-Freund makes concise summary in his Introduction to REvwer, TnE I:stitumtons of Pritate Law and Their Soctal Function (Kahn-Freund ed. 1949): "Positivism is a utopia. The law is neither consistent nor self-sufficient. Whatever theorists may say and whatever he himself may think and say, the judge constantly recurs to an analysis, articulate or inarticulate, of the moral, social and economic function and effect of the rules and principles he applies and of his own decision."

Contrast Sereni, On Teaching Comparatice Law, 64 HAnv. L. Rev. 770, 776 (1951), who suggests that "a law course should study the law from within and in itself rather than in relation to other standards of human conduct." He adds: "Although the study of law as a sacial institution is an important topic, it belongs to the realm of social science, rather than to the curriculum of a law school, inasmuch as such a study deals with the law as an aspect of social behavior."

21. Judge Jerome Frank in Are Judges Human?, Counts on Trun e. X (1949), ofiers an informal account of the factors that may affect decision. See also Carrozo, Tre Nature of the Judicial Prccess (1921); Green, Judge and Jurx (1930); Coneti \& Cohen, Readings in Jurisprudence and Legal Philosophy c. VI (1951); Von Miehren, Book Review, 63 HARv. L. Rev. 370 (1949) (referring to continental judges); Doughs, Stare Decisis, 49 CoL. L. Rev. 735 (1949) ; Frankfurter, Some Reficctions on the Reading of Statutes, 47 COL. L. Rev. 527 (1947). 
the facts of a particular controversy, the competing claims of the parties, and the standards invoked (comprising both technical legal doctrines in terms of rights, duties, powers, property, title, contract, tort, sovereignty, due process, and so on, and policy propositions in terms of basic community values), as well as the whole community context. ${ }^{22}$ Predispositional variables inclucle the attitudes (demands for values, identifications, and expectations), skills, class positions, and character structures of decision-makers. ${ }^{23}$ It is, therefore, obvious that different decision-makers responding to different variables may in cases which a disinterested observer would regard as comparable use the same technical doctrines to reach different results or different technical doctrines to reach the same results. ${ }^{24}$ Hence, comparison even of technical doctrines can be made meaningful only when such doctrines are located in the respective decision-making processes in which they are being used and observations are made of the equivalences and non-equivalences in effects which different decision-makers responding to different variables achieve by the use of such doctrines. ${ }^{25}$ Comparison which extends beyond the traditional fixation upon technical doctrine to the comprehensive and systematic investi-

22. For elaboration see McDougal, Future Interests Restated: Tradition Versus Clarification and Reform, 55 HARv. L. Rev. 1077 (1942); Lasswell \& McDougal, Lcgal Education and Public Policy; Professional Training in the Public Interest, 52 YALE L.J. 203 (1943).

23. The relevance of such variables is outlined in detail by LASSWEL, POWER AND Personality (1948).

Mead in The Study of National Character in The Policy Sciences (Lemer \& Lasswell eds. 1951) describes the present state of comparative research.

24. Demand for a "functional approach" to comparative study has been made many times. Thus, Rheinstein in a classic and highly influential article on Teaching Comparative Law, 5 U. OF CHI. L. Rev. 615, 617 (1938) wrote: "The statement that law is at means of social control and organization has almost become a commonplace. Not all the implications of this proposition have been fully realized, however. For legal science, it implies the task of inquiring into the social function of every legal rule and institution."

More recently in Report of Institute in the TeACHING on InTERnational AND Comparative Law, Assoctation of American Law Schools 83, 111 (1948) Rabel succinctly states: "Every comparison, of course, needs a common denominator, a tcrtitmm comparationis. For me in these fifty years past, this has always been the social purpose of the rules and the service of the concepts to this purpose. This is now aptly called the functional approach."

The demand for inquiring into functions is, however, but the beginning of insight. Further questions are "functional" for whom, against whom, with respect to what values, determined by what decision-makers under what conditions, how, with what effects. Comprehensive guiding theory must take all these questions into account.

25. Lepaulle makes the point forcefully: "First, it must be clear that a comparison restricted to one legal phenomenon in two countries is unscientific and misleading. A legal system is a unity, the whole of which expresses itself in each part; the same blood runs in the whole organism. Hence each part must necessarily be seen in its relation to the whole. An identical provision of the law of two countries may have wholly different moral backgrounds, may have been brought about by the interplay of wholly different forces, and hence the similarity may be due to the purest coincidence-no more significant than 
gation of the other important variables that affect decision must clearly require the study and exposure of decision-making processes in their entirety.00

It may perhaps bear emphasis that the decisions requiring study are not merely governmental decisions, that is, decisions by officials who have formal authority and are expected by community myth to make important community decisions. Formal authority and effective control may or may not be conjoined in the same decision-makers in any given community. ${ }^{27}$ Effective control over decision may in varying degree be located in governmental institutions, but it may also in degree equally varying be located in political parties or pressure groups or private associations. The individuals who in fact make the decisions may rely for their power not upon formal authority but upon wealth, enlightenment, respect or other values. ${ }^{28}$ The degree to which the

the double meaning of a pun." The Function of Comparative Lazi, 35 HARv. L. REv. 83S, 853 (1922).

See also Pound, Philosophy of Law and Comparatize Law, 100 U. of PA. L. REv. 1 (1951): "But a fruitful comparative law must involve more than comparison of legal precepts, important as that is. There should be comparison of systems of law as systems, not merely precept by precept." Cf. Schmitthoff, The Scionce of Comparaliec Law, 7 CAзrB. L. J. 95, 97 (1939).

The big question is, however, how an organization of studies can be perfected which will permit either the comparison of systems or the making of partial comparisons which can contribute to comprehensive understanding.

26. Miargaret Miead generalizes: "The science of culture can insist, therciore, that when we consider contrasting types of behavior we shall attend always to the complete system, and that random, indiscriminate citations of cultural contrasts in detail be strictly recognized for what they are, iconoclastic polemic material, ammunition for agitators, but with no scientific validity." The Comparative Study of Cullure and The Purposize Cultivation of Democtatic Values in Conference on Science, Prulosophy niso Reugion 56, 58 (1942).

27. For development of these distinctions in detail see Lasswers \& Kaplasi, Powes and Society cc. V, VIII (1950); MfcDougal, Law and Poucr, 46 Ass. J. I3is'. L 102 (1952).

23. Mialinowski, Introduction to Hogrin, LAw ANid Ordes ni Polyiesu Xwi (1934) urges students "never to forget the living, palpitating flesh and blood organism of man which remains somewhere at the heart of every institution."

Similarly Radeliffe-Brown in his Preface to Fortes \& Evars-Yritchanso, Arsucas: Polttrcal Systears xxiii (1940) offers, in a description of the "state," insights too often forgotten: "In writings on political institutions there is a good deal of discussion about the nature and the origin of the State, which is usually represented as being an entity over and above the human individuals who make up a society, having as one of its attributes something called 'sovereignty' and sometimes spoken of as having a will (Law being often defined as the will of the State) or as issuing commands. The State, in this sense, does not exist in the phenomenal world; it is a fiction of the philosophers. What does exist is an organization, i.e., a collection of individual human beings connected by $a \mathrm{com}-$ plex system of relations. Within that organization different individuals have different roles, and some are in possession of special power or authority, as chiefs or elders capable of giving commands which will be obeyed, as legislators or judges, and so on. There is no such thing as the power of the State; there are only, in reality, powers of individualskings, prime ministers, magistrates, policemen, party bosses, and voters. The political 
technical legal doctrines of a community represent reality or illusion may in great measure depend upon the exact inter-relations of formal authority and effective control. ${ }^{29}$ Thus, a constitutional prescription of doctrines for the maintenance of civil liberties and an attempted balancing of power between legislative, executive, and judicial institutions may succeed in a community where effective control is widely dispersed but fail in a community where legislative, executive, and judicial institutions remain subject to a concentrated effective control that is hostile to civil liberties. ${ }^{30}$ Hence, comparative study concerned for the realities of practice as well as for myth must take into account not only the structures and processes of formal authority but also those of effective power, and of their interrelations.

The purposes that may move different observers to the comparative study of decision-making processes are many and varied. ${ }^{31}$ Relatively recent surveys include such itemizations as "the general purpose of any science; the search for truth," increase in the understanding of the legal rules and institutions of one's own country, increase in the understanding of foreign laws and of assistance to practitioners, the unification of laws, increase in the understanding of international law, improvement of legislative policy and definite legislative purposes, "developing understanding of the role of law as a social institution,"

organization of a society is that aspect of the total organization which is coneerned with the control and regulation of the use of physical force. This, it is suggested, provides for an objective study of human societies by the methods of natural science, the most satisfactory definition of the special class of social phenomena to the investigation of which this book is a contribution."

29. Cf. Stone, The End to be Served by Comparative Lazw, 25 TULANE L. Rev. 325, 332 (1951): "We must study the history, the politics, the economics, the cultural background in literature and the arts, the religious beliefs and practices, the philosophies, if we are to reach sound conclusions as to what is and what is not common." See also Gurtertoge, Comparative Law 174 (2d ed. 1949).

30. An illustration borrowed from a lecture by Professor Franz Neumann.

31. The literature upon the purposes of comparative study is voluminous. In addition to the articles already cited, the following items are among the many that deserve attention: Gutteridge, Comparative Law c. I (2d ed. 1949); Davd, Traite ElÉsentalue de Droit Civir. Comparé 1-214 (1950) ; III Wigmore, Panorama of the World's Legal. Systems 1119 (1928); Schlesinger, Comparative Law Cases and Materials 8 (1950); II Bryce, Studies in History and JuRisprudence 607, 619 (1901); Pollock, The History of Comparative Jurisprudence, 5 J. Comp. Leg. 74 (1903); II Vinogradoff, Collected Papers (1928) (various essays on jurisprudence); Hourwl, Fundanental Legal Conceptions 340 (Cook ed. 1923); Ehrlich, Comparative Public Law and the Fundamentals of Its Study, 21 Col. L. Rev. 623 (1921); Hazeltine, The Study of Comparative Legal History, 1927 J. Soc. Public Tencuers of LAw 27; Escarra, The Aims of Comparative Low, 7 TEMrP. L. Q. 296 (1933); Lambert, Comparative Law in 4 ENCYC. Soc. Sa. 126 (1937); Cohn, Task and Organization of Comparative Jurisprudence, 51 JURID. Rev. 134 (1939); Friedmann, A Comparative Laze Course at Mclbournc University, 1 J. Soc. Public Tencaers of Law 274 (N.S. 1949); Lawson, The Ficld of Comparative Law, 61 JuRtD. Rev. 16 (1949); Auld, Methods of Comparative Jurisprudence, 8 U. of Toronto L. J. 83 (1949); Hazard, UNESCO and the Lam, 4 Recolv 201 (1949); Dainow, Teaching Methods for Comparative Lazv, 3 J. of LEGs. Ev. 388 (1951). 
decreasing the exercise of arbitrary power and increasing the rule of law, and "the instilling of values." 32 It is believed, however, that there is today, for scholars who demand and share responsibility for the values of a free society, one central purpose which can unify and revivify all these other purposes. Most broadly conceived, that central, over-riding purpose is, in accord with the opportunity and need we have urged above, the clarification for all our communities-from local through national and regional to global-of the perspectives, the conditions, and the alternatives that are today necessary for securing, maintaining, and enhancing basic democratic values in a peaceful world. ${ }^{33}$

The potentialities of the comparative method for value clarification at different community levels have just begun to be demonstrated. ${ }^{34}$ Enough creative comparative studies have been made, however, to suggest that the method can be used to clarify the values of the peoples of the world, not for simple verbal unification or for promoting any particular world organization, but rather for demonstrating the deep underlying equivalences in their demands for the values of a free society, for reinforcing their expectations that they can best maximize their own individual values in such society, for cementing their loyalties to such society, for increasing the identifications of all free peoples with each other, and for in general establishing the consensus and predispositions necessary to effective cooperation in whatever forms of organization may be most appropriate under contemporary conditions. ${ }^{35}$ It

32. These itemizations are taken by random sampling from Rheinstein, Tcaching Comparative Law, 5 U. of CHI. L. REv. 615 (1938); Hazard, Comsaratiec Lawe is Legal Education, 18 U. of CHI. L. REv. 264 (1951); Stevenson, Comparatizec and Forcign Las in Anerican Law Schools, 50 COL. L. REv. 614 (1950) ; III Yntema, Roman Law as the Basis of Comparative Law in 2 LAw: A Century of Progress 346 (1937); and F. Stone, End to be Served by Comparative Law, 25 Tulane L. Rev. 325 (1951).

33. Cf. Riesenfeld, Book Review, 3 J. Legal Ed. 620 (1951); Sayre, Book Review, 36 IowA L. Rev. 585 (1951) ; Sturges, The Quest for World Low and Ordor, 22 Tula:ie

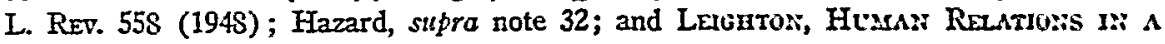
Changing World 101 (1949).

34. The most significant and dramatic demonstration has been in the United Nations Human Rights program. For introduction, see LaUterpacht, INTERNATIONaL LAW AND Human Rights (1950); Robertson, The Europan Conzention for the Protcction of Husman Rights, 27 BRT. Y. B. INT'L. L. 145 (1950).

35. The theme is developed in McDougal \& Leighton, The Rights of Man is the World Community: Coustitutional Illusions versus Rational Action, 59 YALE L. J. 60, 108 (1949).

The possibilities of discovering deep underlying equivalences in values, despite differences in institutional doctrines and practices, are emphasized by many observers. See, for examples, Murdock, The Consmon Denominator of Cultures in Tre Scrence or Min:: IN THE WORLD CRISTS 123 (Linton ed. 1945) and Lergeton, Huaran Reantions Ir: A Changing Wordo 161, 162 (1949): "Related to the lack of a functional view of human affairs is a diffeulty in seeing common qualities and common dynamic patterns when they appear in widely different contexts, or in strikingly different shapes. If one does not think: in functional terms, it necessarily follows that he will not perceive how functions exist 
has already been sufficiently urged that the method is indispensable to understanding of the world power process and the various component processes that condition every measure, external or internal, cooperative or unilateral, in every community. Certainly no other method promises more in the invention and adaptation of felicitous alternatives, doctrines and procedures, for the achievement of our emerging goals, whether world, regional, national, or local. . $^{36}$

For achieving its central and other important purposes, it will be essential for comparative study to discover and apply both a comprehensive guiding theory and the techniques adequate to describing comparable decisions through time and across political boundaries. The comprehensive guiding theory that is necessary must permit, and require, an investigator to categorize the facts to which decision-makers respond in terms of value changes (as contrasted with doctrinal technicalities) which transcend the peculiarities of national or regional institutional practice; to take into account all the important variables that affect decision and to clarify the doctrinal variables, and the predispositions that decision-makers bring to decision, in terms of the basic individual and community values sought; to make precise description of the trend of decisions through time and to appraise the impact of different technical doctrines among other variables in conditioning different decisions; to identify in detail the community values in fact at stake in a flow of decisions and to assess the compatibility of alternative decisions with values so clarified; and, finally, creatively to explore the whole range of alternatives, in both doctrine and institution, that may be adopted or invented for maximizing decisions in accordance with community values under the given conditions. ${ }^{37}$ Specific techniques in the application of this guiding theory must, drawing

like recurrent themes in an enormous variety of different situations. Non-scientific thinking tends to generalize on the basis of gross similarities and differences of structure, not on similarities and differences of dynamic process. ...

"It seems impossible that a jelly-fish and a man can have the same ground plan, so great is their difference in appearance; yet they share metabolism, growth, reproduction, respiration, irritability, and much else."

For expressions of the possible range of legal equivalences see Rheinstein, Book Review, 64 Harv. L. Rev. 1387 (1951); Neumann, Book Review, 64 Pol. Scr. Q. 127 (1949) (indicating a certain lack of originality in Soviet law); Kahn-Freund, Introduction to Renner, The Institutions of Private Law and Their Social Function (Kahn-Freund ed. 1949); Jackson, Some Problems in Developing an International Legal System, 22 TeNrP. L. Q. 147 (1948) ; Eder, A CoMparatrve Survey of ANGlo-American and Latin-Anerican Law 4 (1950); and Friedmann, A Re-Examiration of the Relations between English, American and Continental Jurisprudence, $20 \mathrm{CAN}$. B. Rev. 175 (1942).

36. Hug, The History of Comparative Law, 45 HARv. L. REv. 1027 (1932) offers some indication of the tremendous diffusion of legal techniques in various epochs. A helpful recent contribution is Lenhoff, America's Legal Inventions Adopted in other Countrics, 1 BufFato L. Rev. 118 (1951).

37. These are the indispensable procedures in a "policy oriented" approach to any legal study. Lassivell \& MCDougal, Syldabus, Law, Science, and Policy (1950). 
upon all the insights and skills of contemporary scientific study of culture 33 and personality, ${ }^{39}$ be adequate for performance of all the indicated tasks.

It is not our pretension that we can here proffer theory and techniques of the necessary perfection. Their discovery or invention will require long work by appropriate specialists. It is believed, however, that a beginning contribution can be made to one possible, over-all organization of comparative studies which might enable scholars, with requisite skills and resources, to produce some of the information so urgently needed today.

The prime need is for an organization of studies which will permit the location of any particular decisions being compared in a context which will reveal the degrees of their equivalence or non-equivalence in effects on values. ${ }^{40}$ The organization we propose is, therefore, explicitly oriented to

38. The Policy Scances (Lerner \& Lasswell eds. 1951) offers survey and biblio-

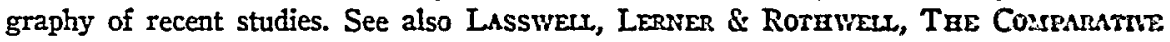
Study of Elites (1952); Lassweli, Lerner, \& Pool, The Cosparative Study of Symirols (1952); and Lasswell, Leites, \& Associates, Language of Politics (1949).

The rich insights of Mralinowsli remain largely unused by legal scholars. See Malinowski, A Sctentific Thdory of Culture and Other Essays (1944); Tre Dymasics of Cultural Change (1945); Introduction to Hogbin, Law aisd Ondez mi PolyNESIA (1934); A New Instrument for the Interpretation of Loal-Esfacially Primititec, 51 Yate L. J. 1237 (1942); 1 Corat Gardens and Their Magic c. XI (1935); Canse aNd Custosi IN SAVAGE Soctery (1926). Other recent books rich in suggestion are

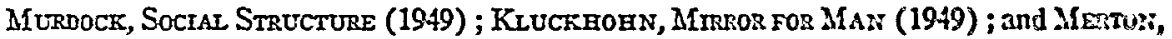
Soctal Theory and Social Structure (1949).

Significant studies more directly related to power processes are UNESCO, Co::tearporary Political Science: A Survey of Mietrods, Researci a:id Teichime (1950); Tmasheff, AN Introduction to the Sociology of LAw (1939); Rusche \& Krrchemerare, Punishament and Soctal Growtr (1939); MincIver, The Wen of Governatent (1947); Merriasr, Systeratic Politics (1945); Mosca, The Rulisg CLAss (Livingston ed. 1939).

Widely heralded recent books such as Towarb a Gexeral Theory of Actioz: (Parsons \& Shils eds. 1951) and Parsons, The Soctar Systear (1951) seem to lack sufficient orientation in power processes and to take too little account of predispositional variables to be of direct use to legal scholars. Professor M. J. Levy, Jr. of Princeton will publish in the summer of 1952 a book, THE STRUCTURE of SOCIETY, which will explicitly apply the same general approach to the comparative study of societies.

39. Introduction to a vast literature may be obtained through Dolnasb \& Mruers, Personality and Psychotherapy (1950) ; Money-Kyrle, Psychonanlyysis aitd Politics (1951) ; Personality and Political Crisis (Stanton \& Perry eds. 1951); Karsdiner and Associates, The Indrvidual and His Society (1939); and The Psycrological Frontiers of Soctety (1945); Kardiner, The Miare of Oppression c. II (1951) ; Alesander, Our Age of Unreason (Rev. ed. 1951); Fluger, MLari, Morals AND SOCtety (1945); and West, Consctence AND Society (1945).

40. Dean Pound's theory of "interests" could serve this purpose if appropriate operational indices were supplied for each interest and the various interests vere explicitly related to the predispositions of decision-makers. See Pound, A Surecy of Social Intcrests, 57 Harv. L. Rev. 1 (1943); J. Stone, The Province and Function of Law ce XXXXII (1946). Without such amplification, the theory leaves obscure what is being com- 
values and seeks to relate all decisions in a hierarchy of power processes to the values they affect.41 It assumes that the value-shaping processes in any community, however limited or inclusive in time and space, can be conveniently described in terms of interdependent value-variables and institutions. In terms of value-variables one may describe a community process as people using such values as power, respect, enlightenment, wealth, well-being (including safety, health, character, comfort), rectitude, skill, and affection as bases to effect desired distributions of these same values among themselves and others. Institutions are the patterns of practices, the myths and techniques, the doctrines and procedures, by which such distributions are effected and may of course, vary in infinite detail from community to community. ${ }^{42}$ Fruitful comparisons become possible when basic values are clarified and the infinite variety of institutional detail is appraised in terms of its effects on such values. ${ }^{43}$ For comparisons either as between communities or in a single community through time, the important general questions are: what are the structures and processes, the doctrines and practices, by which each value is shaped and shared, and what are the effects of these structures and processes, these doctrines and practices, on each other value? With respect to each value, in detail, what are the degrees of equivalency or difference in doctrine, and in technical procedures? Thus, one may ask of any community or of a

pared, how the comparison is made, and by what criteria results are appraised. These consequences are apparent, despite a fascinating collection of materials, in SuMPson \& J. Stone, Cases and Readings on Law and Society (3 Vol. 1948-49). See McDougal, Book Review, 45 AM. J. INT'L. L. 399 (1951) and the earlier indication of the dificulties in Dean Pound's theory in Lepaulle, The Function of Comparative Lazu, 35 Harv. L. Rev. 838 (1922).

41. The writer some years ago projected a more ambitious outline in collaboration with Dr. Karl Graf, of Switzerland, and what is presented here draws in some measure on the earlier collaborative work.

42. More detail on this type of analysis appears in LASswert \& KAPLAN, POWER AND SOCIETY (1950).

The UNESCO volume on Contearporary Political Science (1950) offers few alternatives. In an essay on The Methods of Political Science, Chiefly in the Unitcd Statcs (at page 77), Cook writes: "Here I wish only to urge that possibly adequate classifications may rest on major human motivations, or human needs (the two are not identical), if these can be adequately separated, for postulational and observational-experimental purposes, or as major, permanent, and virtually omnipresent institutions."

43. Bodenheimer, Book Review, 3 Stan. L. REv. 755 (1951) graphically depicts a dilemma of "the Scylla of over-generalization" and "the Charybdis of exaggerated specialization." He writes: "If the teacher chooses the method of selecting some specific and narrow topics... he is in danger of losing himself in details and fostering in his students a type of specialized thinking apt to mistake the trees for the forest. If, on the other hand, he is inclined to paint with a wide brush, and to indulge in broad generalities regarding the basic differences or similarities between the world's legal systems, he takes the risl: of giving an oversimplified and faulty picture."

Fulda, Book Review, 36 CoRnell L.Q. 185 (1950) wisely insists: "Without some fundamental philosophy which brushes aside millions of details the value of comparative law as a subject of organized study would remain obscure." 
series of communities: What are the pozer structures and processes of this community? What are the roles of particular doctrines and practices in the shaping and sharing of power? What are the effects of these structures and processes, these doctrines and practices, on the shaping and sharing of all other values? What are the wealth structures and processes? What, again, are the roles of particular doctrines and practices and what are the consequences of the processes as a whole for all other values? And so on for each important value in the community or communities under study. ${ }^{44}$

An outline, though brief and at highest level abstraction, may make clearer the type of over-all organization of studies we suggest. Under the four main headings of Power Processes, Value Processes, Private Associations, and Policy Procedures, and with more or less impressionistic indication of the structure and type of inquiry under each heading, the outline follows.

\section{Global.}

\section{Power Processes}

A comprehensive picture of the world power process must identify the participants and describe the interactions in which they influence each other, the bases of their power (in control over people, values, institutions), the practices they engage in (ranging from volition-procedures to coercion), and the effects they get (in control over people, values, institutions). ${ }^{45}$ Nationstates are still by far the most influential participants in this process and most of the important decisions in application of the doctrines of traditional public and private international laws as well as of municipal doctrine are made by officials deriving authority from nation-states. ${ }^{10}$ Inquiries that would reveal relevant predispositions and practices about the globe might be organized as follows:

A. Interactions. ${ }^{47}$ For the admission of new groups to the formal processes of international law and organization, nation-states have evolved a curious

44. RIEsenfeld \& MAaxweir, Modern Soctal Legislation (1950) which is organized about the value we would describe as "well-being" indicates the potentialities of a value by value analysis.

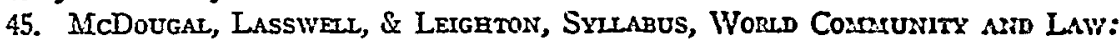
A Contzarporary International. LAw (1950) presents a detailed outline with bibliography.

46. Cf. Niemeyer, Book Review, 4 Wortd PoLrircs 2S2 (1952): "We need to say and repeat often that the essential prerequisites for a society, a monopoly of force and a broad consensus about the uses of such centralized force, do not exist on a world seale. This means that any rational approach to the problem of international order must take fully into account the existence of a multitude of centers, each capable of exercising a certain amount of ordering functions. The play of forces among these centers, the stability of their positions, and their power relative to each other are phenomena of fundamental importance to the problem of international order."

47. For sake of brevity and special relevance to comparative study the general analysis is here somewhat abbreviated. A more comprehensive outline appears below with respect to the National Power Process. 
ceremony called "recognition." The granting or withholding of this ceremony, with its attendant benefits in diplomatic intercourse and access to formal power, is used by each state against new groups as an instrument for improving its own power, and other value, position. The important questions are: who within any given nation-state is authorized to bestow recognition on another body politic; by what standards in international and national policies does the recognizing official act; by what formalities is the ceremony effected; what are the consequences in terms of access to formal authority and other values of recognition as between nation-states and with respect to the claims of private individuals; what meaning, if any, in terms of such consequences can be given to traditional distinctions between recognition $d c$ jurc and de facto, recognition of governments and states, and conditional and unconditional recognition?

$B$. Bases of Power. The effective power of a nation-state is determined, not only by resources and geographical position, but also by its practices in controlling people and resources and the efficiency of its organization for internal and external purposes. People are controlled by selective admissions and expulsions, by differential admission to citizenship and to the various value processes (discriminations against minorities on grounds of race, color, alienage, opinion, etc.), and by the systematic positive use of various values to secure conforming behavior (treason, espionage, sabotage, military service, compulsory labor, compulsory indoctrination, control of weapons, and so on). Non-governmental groups such as political parties, pressure groups, and private associations are managed with varying degrees of encouragement, regulation, policing or suppression. Resources and wealth processes, including the functions of allocation, planning, development, production, and distribution, are controlled in a wide range of practices between the polar extremes of regulated private enterprise and complete governmentalization. The efficiency of internal institutions in mobilizing manpower and resources into an effective military establishment, the degrees of independence, in formal authority and fact, from other power units, and the forms of alliance with other power units, 'for the positive support of policies, vary greatly from nation-state to nation-state. Comparative study of all these variations in bases of effective power could contribute much more to real understanding of the world power process than the customary reiteration of the doctrines of public international law about dual nationality, acquisition and loss of territory, and sovereignty.

C. Practices. The practices by which nation-states engage each other range between the polar extremes of peaceful procedures and war, and present a continuous process of attack and defense by all weapons, diplomatic, ideological, economic, and military. The important question for comparative study is, in general, how the foreign affairs power is structured, and operates, in different states. What is the structure of formal authority (constitutional pattern; division of powers between executive, legislative, and judicial insti. 
tutions; division, if any, between national government and internal units) and what is the structure of effective controls (who actually makes the decisions and subject to what pressures)? How do structure and operation in any given state compare with that in others when measured by such criteria as democracy (widely shared power), efficiency (quickness, flexibility, rationality in respect to values), representativeness of national interest, responsibility to other nation-states, and maintenance of civilian supremacy? What, in detail, is the constitutional competence to negotiate and conclude international agreements, how are such agreements made internally binding within the nation-state, by what criteria do officials interpret such agreements, and by what criteria and procedures are they terminated, internally and internationally? Where, in further detail, is the war power located, what is its scope, and to what, if any, commitments does the nation-state subscribe for the initiation and conduct of hostilities? Enough studies have been made to indicate the rich supplementation that might be added to the doctrines of public international law. 48

D. Effects. The effects that a nation-state achieves, from its bases of power and by its practices, in terms of control over people and resources embrace all of the problems of the field of Private International Law as traditionally conceived. ${ }^{49}$ The most general question is over what events (value changes) a nation-state will exercise its power to effect its own policies and with respect to what events will it limit its exercise of power in expectation of similar reciprocity in self-restraint by decision-makers in other nationstates. In specific controversies some one nation-state has effective control over persons or resources which it can use as a base for power and the issue is whether it should exercise its power to make its own policy for the events under review, or whether, out of deference to its own long term interests or to the interests of other states or to a regional or world community interest, it should dispose of the controversy either by refusing to exercise its power or by applying policy formulated by another state. For resolution of controversies of this kind, decision-makers have customarily invoked as justifications for decision certain mystical notions of "jurisdiction," "territoriality," "nationality," "domicile" and the like, and reified derivations from "contract," "property," "tort," "crime," and so on, all of which made a confused reference at one and the same time to facts, policies, and official responses to facts. The whole body of doctrine is more than ordinarily nebulous and confused. Rational inquiry

48. For examples, see Preuss, The Execution of Treaty Unliestrons Turgich Internal Law-Systear of the United States and of Sosie Otrer Coumiture, Pro-

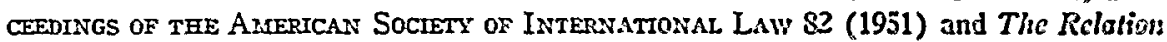
of International Law to the Internal Law in the French Conslitutional System, 44 Ais. J. InT'L L. 641 (1950) ; Deener, International Law' Prozisions in Post-IV'orld W"War II Constitustions, 36 CORNELI L. Q. 505 (1951).

49. The fruitfulness of comparative study has been superuly demunstratcd by Prufessor Rabel's monumental work. Rabel, The Conflict uf Laws: A Corsparatite Strury (3 Vol. 1945-50). 
must begin by differentiating controversies in terms of significant differences in fact: who the parties are, nation-state versus individual, individual versus individual, national or non-national, corporate or non-corporate; what values (power, wealth, etc.) are at stake for the parties, for the nation-state of the decision-maker, for other nation-states, for regional groupings, and for the world community; whether the value changes contested took place by agreement or deprivation, volition or coercion ("contract," "tort," "crime," "expro priation," etc.) ; the locus of each significant event in the value changes contested (within the territory of the decision-maker, within the territory of others, on the high seas, etc.) and the territorial range of the effects of such events; the locus of any resource affected and the type of resource (land, obligations, ships, etc.) ; the types of "acts of state"-legislative, executive, or judicial-that have occurred in nation-states other than that of the decisionmaker; whether the nation-state of the decision-maker has "recognized" the other nation-state purporting to declare policy for the events in question; and so on. ${ }^{60}$ With types of controversies so differentiated, comparative survey of how decision-makers located in different nation-states apply traditional technical doctrines to different controversies might permit effective appraisal of such doctrines in terms of their consequences for the values of all interested parties. It has long been demonstrated that "territorial" notions of jurisdiction are largely outmoded, that too much emphasis upon the physical locus of an event is irrational because what matters to individual citizens as well as to nation-states is not simply where an event takes place but the total effect on values. ${ }^{51}$ The task of constructing a new and rational doctrine to take the place of the outmoded remains, however, a challenge to the comparative study of Private International Law.

\section{National.}

The power process of any particular nation-state operates within the context of the world power process and both affects and is affected by the larger context. ${ }^{52}$ Above, our principal concern was for effects upon the world process. Here our concern must include as well effects upon the distribution of values within the nation-state. Comprehensive study must again identify participants and describe arenas of interaction and influence, methods of access or admission to such arenas, bases of power, practices, and effects. Participants may be conveniently categorized as government, political parties, pressure groups, private associations, and individuals. Government refers to the officials established by formal authority and who are expected to make the important

50. The beginnings of such an approach are illustrated in SAlongs, Private INTERNational Law (1950) (supplement I). Professor C. J. Olmstead, of New York University Law School, has in preparation a more detailed outline.

51. Cook, The Logical and Legal Bases of the Conflict of Laws (1942).

52. A more detailed and illustrated outline has been prepared by the writer and $\mathrm{Mr}$. Edward McWhinney of Australia. 
decisions sustained by community coercion, political parties to groups who present candidates and platforms at elections, pressure groups to organizations primarily devoted to the manipulation of government and political parties, and private associations to groups primarily designed for the shaping and sharing of values other than power but which seek power effects. Individuals act in both organized and unorganized ways. In any nation-state power processes affect other value processes (wealth, enlightenment, respect, etc.) and other value processes in turn affect the power processes. Hence description may conveniently begin with the broad outlines of power processes and then develop, in spiral fashion, the details of doctrine and practice in more precise description of the role and effects of power in each of the other value processes. Relevant comparative inquiry into the broad outlines of power might, beginning with government, proceed as follows:

A. Arenas. The call here is for the interactions in which power is shaped and shared and these may be described in terms of the interrelation of decisionmakers in conventional institutional structures-constituent or amending, legislative, executive, administrative, judicial-and in effective control groups.

B. Admission. The question is how officials obtain access to positions of power and all qualifications, elections, and appointment practices are relevant.

C. Bases of Pozver. The general inquiry is how formal authority, to invoke and apply community coercion, is divided among officials. Divisions may be made between the delusively functional institutions-legislative, executive, administrative, judicial-or geographically (with varying degrees of centralization or "federalism") between national and provincial or local authorities. Comprehensive survey and comparison require a precise indication of exactly what powers are granted to what officials, over whom, with respect to what values, and subject to what conditions or limitations. Formal authority and other factors may of course invest officials with effective control over violence, resources, enlightenment, and other values, and the varying degrees of such control are unquestionably of the greatest significance to fruitful comparative study. Degrees of effective control may perhaps, however, be more easily appraised after completion of other inquiries.

$D$. Practices. The practices by which officials participate in the shaping and sharing range from the maintenance by coercion of a framework of order to the direct provision of goods and services. The framework of order is designed to secure within the limits of community policy the expectations created by private agreement and volition, to protect varying degrees of private control over resources, to insure individuals against arbitrary deprivations, and to maintain conformity with certain standards of rectitude in behavior. Both the maintenance of a framework of order and the direct provision of goods and services require the formation and application of policy in a series of steps ranging through the collection of intelligence, the clarifcation and recommendation of proposals, authoritative enactment or pre- 
scription, invocation, interpretation, application in specific instances, and termination. The task of comparative study is to expose how these different functions are performed in different nation-states and to appraise differences in performance.

E. Effects. The effects that officials achieve by their practices require appraisal not only in terms of the degree to which power is shared but also in terms of consequences for the distribution of each major community value. Hence detailed appraisal requires more specific investigation (outlined below) with respect to each value.

Delineation of the varying rules of political parties, pressure groups, private associations, and individuals requires the asking and answering of the same fundamental questions, appropriately modified, as to arenas, admission, bases of power, practices, and effects. The importance for comparative study of party systems, pressure group operations, private association controls, and individual powers and freedom may safely here be assumed.

Building upon this broad description of power processes, more intensive exploration of the special role and effects of power in each of the other value processes, and of the reciprocal impacts of the various value processes, can seek amplification and detailed elaboration of bases of power, practices, and effects with respect to each major value. For systematic survey and comparison we suggest for each value (wealth, enlightenment, etc.) an outline as follows:

\section{A. Bases of Power.}

1. Formal Authority.

(a) Affirmative Powers. The explicit grants of formal authority to government officials that may be used to affect the distribution of the value under study.

(b) Limitations. The constitutional provisions of doctrines purporting to restrict official power which may be invoked to limit or control the exercise of the powers indicated above.

2. Effective Controls. The structure of political parties, pressure groups, private associations, and unorganized individual activities, with controls over various base values, that conditions the application of both powers and limitations.

B. Practices. The flow of decisions that in fact effects the shaping and distribution of the value.

1. Formal authority. The official decisions applying powers and limitations in shaping and distributing the value.

2. Effective controls. The details of how the non-governmental participants bring their influence to bear on particular decisions.

C. Effects. Final summary of the distribution of the value among the members of the community in consequence of the practices above and on appraisal of impacts upon the distribution of other values. 


\section{Local.}

Exactly the same analysis can be applied to local or provincial power processes with appropriate modification of the detailed questions. ${ }^{* 3}$ The great range of intergovernmental relations that affect local decisions increases the elaborateness of the inquiry into arenas and admissions. The wide variety of general function and special function units and the varying sources of authority in constitutions and from higher levels of government add to the complexity of bases of power. Frequent obliteration of the lines between the conventional institutions of higher levels of government (legislative, executive, etc.) makes even more important the careful specification of functions in describing practices. Effects are sometimes difficult to trace because of the fuzzy hierarchy of responsibility and the impact of many decisions. The fundamental inquiries are, however, comparable and the potentialities of comparative study for understanding and policy guidance are no less. Consider, for example, what careful comparative study in various countries of one principal local problem, the establishment and maintenance of an efficient physical environment, might reveal. A pooling of experience and the best contemporary wisdom about such functions as the control of community design, the regulation of land use, the provision of public services, securing improvements and development, policing, quality in construction and maintenance, protecting consumers against price gouging, and the administration of public controls, might lead to improvements everywhere in the performance of such functions. ${ }^{54}$

\section{Value Processes: Agreements and Deprivations}

Working within a context of broadly described power processes, comprehensive comparative study must next examine the details of how community coercion is employed in different nation-states to channel and control the agreements and deprivations by which individuals shape and share values in community life. Choice of a principle of organization can be made from a number of alternatives. The traditional principle, as we have seen, is that of legal technicality which may not sufficiently transcend national peculiarities and which commonly makes confused reference simultaneously and without discrimination to the value changes to which decision-makers are responding, to the policies by which they justify decisions, and to the decisions that are made. Almost any alternative would seem preferable. One possible alter-

53. A detailed outline has been prepared by Professor W. T. Mallison, Jr., at the George Washington Law School. Our intent in the text here is to present only enough comment to indicate that the same type of analysis is applicable to any power structure at any areal or regional level.

54. For detailed organization with respect to these problems, see MraDougar \& Haber, Property, Wealth, land: Allocation, Planning and Developiseit c. IX (1948). 
native would be an organization value by value in which each value (wealth, enlightenment, and so on) is taken separately for comprehensive and integrated investigation of the various doctrines and practices by which the community controls both agreements and deprivations with respect to that value. An alternative less disturbing to conventional legal predispositions is perhaps to organize by agreements and deprivations, but with the detailed location of both agreements and deprivations in value and institutional context. So long as all variables significant for the effective study of factors affecting decisions, of the consequences of decisions, and of the clarification of community policies are kept explicitly in focus and are not confused, the exact principle of organization is not too important. The mode of organization which we will indicate by brief comment begins, accordingly, with agreements and deprivations, and seeks to add necessary value and institutional orientation.

In a society aspiring to be free the principal mode of shaping and sharing values is by agreement, in the broad sense of volition. Simple deference to human dignity requires that respect be given to individual volition to the extent that it can be kept compatible with over-all community policies in securing and preserving basic values for all members. The generalized task of the "law of contracts" is to establish both a framework within which individuals by their own initiative and agreement can shape and share values and certain limits beyond which volition cannot transgress upon community policies. The two most important questions for comparative study are: To what degree with respect to what values (power, ${ }^{55}$ wealth, enlightenment, etc.) in what varying institutional contexts does this community give effect to private agreement? By what doctrines and practices does this community unity seek to make private agreement effective to this degree in this context? More detailed inquiry requires specification of how certain functions are performed. These may be itemized briefly as:

Fixing Policy Limits. Determining whether a particular agreement in its context is within or contrary to over-all community policies. Agreements for race discrimination, for buying or selling public offices, or for locking up resources from use, may be denied community protection without further consideration.

Securing Intent. Making certain that there is a final expression of intent, an agreement, or behavior that should be regarded as raising expectations in others that a commitment has been made. This is the function that traditional doctrines about offer and acceptance, writing and seal, parol evidence rule, consideration, mistake, duress, fraud, conditions, competence of parties, illusory promises, and their equivalents are designed to serve.

55. Even though power processes have already been broadly described, it is necessary to continue to work with power in order to secure more and more detail of the interrelations with other values and institutional practices. One is reminded of Maitland's metaphor of the "seamless web." 
Enforcement. The use of community coercion to make certain that the promised expectations actually are forthcoming or that appropriate redress is made. This is the function of the traditional remedies, such as damages, specific performance, injunction, imprisonment. The principal question is what remedy in this context of value and institution is the most economical in securing the most efficient operation of private agreement to the extent preferred.

Protecting against Third Parties. Preventing third parties from interfering with promised expectations or from taking the benefits of agreements without appropriate assumption of burdens.

Honoring Transfer of Benefits. Determining conditions under which promises may transfer benefits of agreements to others.

Construction. Determining the relations of the parties with respect to exigencies they did not foresee or foresaw only vaguely.

Termination. Putting an end to the agreement when it has served its purposes or when, though lawful in the beginning, it has become inimical to community policy.

Subjection to Community Clainus. The imposition of appropriate community burdens in the form of taxation, eminent domain and exercises of the police power.

It is reasonably obvious that with respect to all these functions both community policies and the responses of decision-makers will vary with the values primarily and secondarily at stake and with the priorities ascribed to such values in varying institutional contexts. Hence any significant comparative study of how these functions are performed in different communities must make cross-categorizations in terms both of the values affected and of an infinite variety of institutional context, such as the resource being used, the presence or absence of competition, and effects on consumers, or of in general such varying details as appear in the contexts of insurance, construction, manufacturing, banking, labor, and so on. ${ }^{\text {to }}$

The kind of specification of context that is necessary, if comparative study of doctrines and practices about agreements is to be made fruitful, may perhaps be indicated by reference to certain agreements and expressions of intent which explicitly concern resources. For the parties to such agreements wealth is commonly the value primarily at stake, but other values may be involved and the degree of their involvement may make a difference to decision and to policy. Thus, with respect to agreements or expressions of intent which seek merely to transfer claims to resources from one party to another, and which, in sum, effect a continuing allocation of the community's resources among private users, the relevant inquiries must cover all the doctrines and

56. Mugller, Contract in Context (1951) indicates the difficulties in focusing traditional materials on one "long-term commercial project." KessLER \& SHars, CAsES on CONTRACT (mimeo. 1950) offer a policy orientation, though somewhat less systematic and comprehensive than we propose. 
practices by which community officials perform the various functions itemized in the paragraph above. ${ }^{57}$ How are the agreements policed to insure that their objectives are within community bounds? How are parties protected from economic duress, onerous time stipulations, and other penalties? What procedures are afforded for securing clear, comprehensive, and uncoerced expressions of intent? How efficient is the public recording system designed to afford protection against third parties? Is it comprehensive, conclusive, and economically ordered? Does it enable promisors quickly and easily to establish their claims, and promisees to know that they are getting what they are promised? And so on.

With respect to agreements or intents that go beyond mere transfer and seek to regulate future uses of resources or claims to wealth, which seek to establish what is sometimes called "deadhand control," the inquiry becomes more complex. ${ }^{58}$ The objective of the parties in such transactions extend beyond wealth effects to effects on all other values. Wealth objectives include both care of dependents and successors and a wide variety of commercial purposes. Non-wealth objectives range from community (promotion of education, advancement of religion, improvement of government, relief of poverty, promotion of health or patriotism, etc.) to private (preventing specified behavior-marrying, divorcing, drinking alcohol, gambling, etc.-by specified persons, or obtaining specified behavior-care of tombstones, pet animals, houses, etc.-from specified persons). The mode of restraint or deadhand control attempted may include the devotion of a fund to specified purposes in perpetuity or for a long period of time, shifts from one person or purpose to another upon future events, ascertainment of beneficiaries only upon some future event, restraints on the anticipation of income or principal, restraints on the alienation of specific resources, the accumulation of income, and restraints on management. The form of wealth may vary through all the protean forms of "land" and funds. The management establishment may or may not include persons entitled to beneficial enjoyment under the transfer. The mode of establishment may be by corporate charter, by unadorned agreement, or by "legal" or "equitable" property forms or other equivalents. Transferors and transferees vary greatly in both value and institutional position and in capacity to affect community values.

Significant comparative study must make allowance for all these and other variables with appropriate precision in survey of how community coercion is brought to bear in performance of all the separate functions itemized above. The critical questions are, in brief, to what degree, for what length of time, and by what modes will deadhand control be honored for the various purposes in varying contexts, and what are their consequences, for all other problems. Answer to these questions is obscured in Anglo-American countries

57. For more detail see McDougal \& Haber, Property, Wealtra, Land: Allocation, Planning and Development 113 et seq. (1948).

58. Id. at 246. 
by the continued use of ancient doctrines which dichotomize "legal" and "equitable" interests and classify "possessory estates" and "future interests" by such temporally exotic terms as determinable fees and possibilities of reverter, fees subject to condition subsequent and rights of entry, reversions, vested and contingent remainders, executory interests, and so on. One task of comparative study might be to determine whether this language serves purposes other than of obfuscation.

With respect to agreements, for one final illustration, whose purpose is primarily to plan or regulate land use among neighboring occupants, the inquiry is scarcely less complex. ${ }^{69}$ The parties to such agreements may of course seek simply efficient use as among themselves, but they may also seek to strike directly against some basic value of the community, as by provisions that resources shall be locked up or that premises can be occupied only under conditions of race discrimination; or to interfere directly with specific community plan, as by restricting to residential purposes land marked out by the community for business or manufacturing development; or to interfere with the efficient operation of the community's planning process, as by providing that specified land shall be used only for specified purposes, such as for hitching racks or fish markets; or to bind land as security for personal gratifications not easily commutated in money, such as for the singing of songs or the croaking of frogs; or to bind land to inefficient and outmoded practices in use and development. The land affected may be located in rural or urban areas and may be of many different forms (surface, air, light, water, minerals, oil, sub-surface, etc.). The uses affected may cover the whole community range: residential, productive, manufacturing, business, public service or utility, or governmental. Durations specified for control may be permanent, indefinite, for a definite period, or temporary. The number of users permitted may include only specified parties or the public generally. The agreement may be evidenced by non-verbal behavior, oral permission, action in reliance, unsealed writing or sealed writing and may be in language of promise or language of grant. The value and institutional positions of parties to agreements may vary greatly. Comparative study must again take all these variables into account if it would resolve the mysteries of easements, profits a prendre, licenses, running covenants, equitable servitudes, and interests "in the nature of" easements, and so on, and their foreign law equivalents, and seriously attempt discovery and appraisal of the effects of differing doctrines and practices.

For protecting their members against unauthorized deprivations, for maintaining certain standards in expectation and behavior irrespective of individual commitment, communities afford various procedures and remedies. When the deprivations are of sufficiently great danger to community and individual values, the violation of authoritative community standards sufficiently gross.

59. Id. at 475 . 
the deprivations may be called "crimes" and the community may itself take the initiative and impose upon offenders certain counter-deprivations of varying degrees of severity, commonly called criminal sanctions. When the deprivations are considered to involve less threat to community interest, they may be termed "torts" or "delicts" or private wrongs, and initiative in invoking measures of redress may be left to the injured parties or their representatives. Effective comparative study of how officials make these decisions and afford appropriate sanctions or remedies requires location, comparable to that suggested for agreements, in value and institutional context.

With respect to deprivations regarded as "crimes," the relevant inquiries may be indicated in broadest outline. ${ }^{60}$ What values in what institutional contexts does each community under study protect by criminal sanctions? Who in what value and institutional position is protected against whom in what value and institutional position? How in detail are conventional "crimes" related to the protection of particular values, such as power (treason, espionage, sabotage, sedition), wealth (larceny, embezzlement, fraud), well-being (homicide, assault, rape), respect (genocide, libel, peonage), rectitude (blasphemy, obscenity, polygamy), affection (adultery), skill (practicing profession without license), and enlightenment (failure to school children)? How is the community organized to formulate and apply standards for protection from such deprivations? What are the special procedures for detection, apprehension, trial, and punishment? How in detail are standards applied in fact through time? What standards, if any, over-ride all value and institutional contexts and what are related to particular contexts and types of deprivation? What defenses are permitted to offenders in various contexts in terms of immunity for age or position, coercion, mistake, mental or physical incapacity, entrapment, consent, former jeopardy, and so on? What are the sanctions invoked against particular offenses and how are such sanctions applied, administered, and terminated? What effects are achieved by various criminal sanctions in terms of securing behavior patterns in accord with established standards? What alternatives are there to such sanctions?

With respect to the deprivations regarded as "torts" or private wrongs, the relevant inquiries are similar. What values in what institutional contexts does each community protect by private remedies against deprivation? Who is protected against whom and how? Again, in detail, are conventional "torts" related to the protection of particular values, such as power (deprivations of access to public office, voting, and effective control groups; improper performance of official functions; false arrest or imprisonment), wealth (trespass, nuisance, ultra-hazardous activities, interference with subjacent or lateral support; conversion, negligence; unfair competition, unatthorized

60. For imaginative demonstration of the potentialities of a value oriented approach see Dession, Crinsinal Laiv Administration and Public Order (1948). Professor Dession is presently making wide comparative applications of his general analysis. Sce Donnelly, The New Yugoslav Criminal Code, 61 Yale L. J. 510 (1952). 
use of trade secrets, interference with contractual relations, misrepresentation; discrimination in hiring, fring, or tenure or in access to labor organization), well-being (assault and battery, malpractice, breach of statutory duty, negligence, ultra-hazardous activity), respect (defamation, malicious prosecution, invasion of privacy, denial of access to public utilities and institutions), rectitude (denial of access to institutions of worship, defamation of religious groups), affection (seduction, alienation of affections, interference with family relations), skill (unauthorized use of trade secrets, denial of access to professions or unions), enlightenment (denial of access to educational facilities or channels of communication, misrepresentation)? How is the community organized to establish and apply standards to such deprivations? What in detail are the standards established and applied with respect to particular deprivations? What distinctions are made between intended and unintended harms, and ordinary and ultra-hazardous activities? IVhat are the doctrines with respect to breach of duty, causation, and matters of defense? What particular remedies-compensatory damages, punitive damages, injunction, restitution-are made available for redress of particular deprivations? How effectively do these remedies secure the established community standards? What alternatives to such remedies are available in insurance practices or public administration or other institutional forms?

\section{Private Associations}

In describing power processes it is necessary to direct attention to private associations in so far as such associations seek direct effects upon power. There is, however, the further task of investigating community doctrines and practices in promoting and regulating such associations for the primary purposes they are designed to serve. For this investigation a convenient division may be made of such associations in terms of primary purposes. That division is between associations primarily devoted to the production and sharing of wealth and those primarily devoted to other values. $\mathrm{We}$ begin with the former.

\section{Associations Devoted to the Production and Sharing of Wcaltit.}

In most general form the relevant inquiry is what forms of association are afforded to whom for what detailed objectives by what methods and how are activities policed in the interests of members and the community. ${ }^{61}$ In common law countries the forms afforded include both unincorporated organizations (agencies, partnerships, joint stock companies, business trusts,

61. Though the associations under examination are labelled "private" to distinguish them from associations directly concerned with power, the formulation of problems is designed to permit comparison of associations in nation-states of vrying degrees of socialization. A more detailed outline has been prepared by Professor Angel C. Cruz of the University of the Philippines. 
and such informal association as joint ventures, syndicates, and pools) and incorporated organizations (closely or widely held, privately or publicly financed). Detailed objectives of the parties include, in addition the production of goods and services and the making of profits, the combining of wealth and effort, limited liability and flexibility in financing, minimum investment, transferability of interest, centralized management, and continuity of existence. Methods of establishment range from private agreement and declarations of trust through compliance with general statutory requirements for organization or incorporation to special legislative franchise. Comprehensive description of how community coercion is brought to bear to promote and police private association requires comparison and contrast of doctrines and practices with respect to all forms of association in the handling of a variety of distinguishable problems, such as (1) the formation of the particular association, (2) financing the enterprise and determining the distribution of profits and losses, (3) management and operation, (4) termination, and (5) subjection to community claims. The type of detail relevant under each of these problem headings may with respect to incorporated organizations be impressionistically indicated as follows: formation (the role of promoters, brokers, underwriters; pre-incorporation agreements; de facto and dc jurc corporations; the structure of the corporate constitution in articles of incorporation and by-laws), finance (assembling of assets, stock issues and funded debts, redemption and retirement of shares; dividend policies; reductions and increases of capital; regulation for protection of investors), management (official structure and distribution of powers, corporate acts, fiduciary obligations of officials, responsibilities to stockholders and others; stockholders' powers, election of officers, derivative suits and other remedies; creditors' powers; control techniques of various groups; impact of management policies on workers and consumers), termination (sale of corporate assets, dissolution, merger and consolidation, reorganization), and subjection to community claims (taxation, eminent domain, and regulation of businesses affected with a public interest). The task of significant comparative study is to survey the handling of these type problems for all forms of association in countries of varying degrees of socialization and to appraise different forms, doctrines, and practices in terms of their impact both on the production of goods and services and on other basic community values.

\section{Associations Devoted to Values Other than Wealth.}

The general inquiry is again what forms of association are afforded to whom for seeking what values and detailed objectives, and how does the community promote and regulate such forms. Most contemporary communities afford forms of association for the shaping and sharing of a great variety of values other than wealth. Among the more obvious itemizations for several values are these: for enlightenment, educational institutions and societies, scientific and research foundations, associations for specialized 
communication; for well-being, charitable and philanthropic foundations, community chests, hospitals, old folk homes, employees' associations; for affection, family organizations, fraternal orders, and private clubs; for rectitude, church organizations, temperance societies; for skill, professional associations, occupational clubs; for power, patriotic societies; for respect, honorary societies, organizations for the advancement of particular groups; and so on. Methods of establishment again cover a considerable range in private agreement, declaration of trust, unincorporated association, incorporation under general law, and incorporation under special "non-profit" provision. Comprehensive survey of how community officials apply "property," "contract," "tort," and "corporation" doctrines in promoting and regulating the associations so established requires both precise determination of values at stake and institutional context and, again, the careful specification of problem information, financing, management, termination, or subjection to community claims. Comparative study which makes such a survey could do much to reveal the varying degrees of freedom and of efficiency in promoting basic values in different societies.

\section{Policy Procedures}

In the context of broad description of power processes and the relation of doctrines and practices about agreements, deprivations, and private associations to basic community values, comprehensive comparative study for policy purposes may seek, finally, to explore in more detail the general procedures by which community coercion is organized and exercised in forming and applying policy. In traditional terms such procedures are referred to as legislative, executive, administrative, and judiclal. It has long been common knowledge, however, that these words have come to refer more to institutions than to specific functions and that an institution labelled by any one of the names may in fact engage in all procedures and perform all functions. It is, accordingly, suggested that effective comparative inquiry requires a more precise demarcation of functions and that such demarcation might be in measure achieved by some such categorization as the following: intelligence, recommending, prescribing, invoking, applying, appraising, terminating. Brief indication can be offered of the type and scope of inquiry under each heading.

Intelligence. The intelligence function of a community is that by which it keeps itself informed and projects its plans. The performance of this function requires the continuous and systematic study of conditions and trends, inquiry into scientific interrelationships, the projection of developmental contingencies, the clarification of goal values into detailed programs, and the invention and appraisal of alternatives of action. The important question is in what degree and how well these tasks are performed in what governmental or non-governmental institutions. Comparative survey might reveal that intelligence and its use in planning are as necessary to discovering the minimum 
degree of authority and control conducive to democratic values as to maintaining a maximum of governmental oppression and that it is suicidal misidentification to equate planning and regimentation. ${ }^{62}$

Recommending. This is the function of taking initiative, and exerting pressure, to secure specific decisions. Relevant investigation is of the detailed roles of political parties, pressure groups, and private associations in varying contexts. Appraisal might extend beyond condemnation of vicious practices to assay of the conditions under which more groups and individuals might participate in the processes of effective control.

Prescribing. This is the function of the formal enactment of policy into authoritative community doctrine. The most general questions are: How is this function divided among legislative, executive, administrative, judicial, and other institutions? How effectively is each institution organized for the performance of its role? What are the detailed practices of each institution? Appraisal may inquire whether structures and practices are democratic in their responsibility to people affected, whether they are comprehensive in taking adequate account of national, regional, and local interests, and whether they are efficient (economic and prompt) in promoting and securing such interests.

Invoking. This is the function of setting in motion the community machinery for the application of policy to concrete instances. It may be imposed upon community officials (as in the case of crime or violation of charitable trust) or left to private individuals (as in the case of private wrongs or violations of the rules against perpetuities) and the important question is what difference the location of this function makes for individual and community values.

Applying. This is the function of administering authoritatively prescribed community policy in concrete instances. It again is divided among all the conventional institutions of government-legislative, executive, administrative, judicial-and comparative investigation requires specification of the structures and practices of such institutions in performance of the function.

Some indication of the type of specification required may be made by reference to judicial institutions. ${ }^{63}$ These institutions afford certain procedures which the community maintains for settling controversies between contending parties. Such procedures are designed to give both officials and private individuals opportunity (access to formal authority) to test the behavior of other officials and private individuals for conformity with prescribed standards and to secure the application of community coercion for maintaining such conformity. The controversies for whose settlement judicial pro.

62. Lasswell \& McDougal, Syllabus, Law, Science, and Policy (1950); McDougal \& Rotival, The Case for Regional Planning with Special Referenct To NEW ENGLAND (1947).

63. A comprehensive outline of judicial procedures has been prepared by Professors Keith Blinn, J. W. Bunkley, and George Pugh. 
cedures may be invoked obviously cover the whole range of community values and all institutional contexts. The important general questions are: Do procedural doctrines and practices vary in different controversies depending upon the values at stake and differences in institutional context? If so, are such variations based upon rational conceptions of how best to promote the various values in differing contexts? If not, should such variations be made for such purposes? These questions may be made concrete with respect to such various procedural steps as the following: for taking hold of the defendant, for taking hold of the subject-matter of the controversy, for determining place and time of hearing, for enlightening the tribunal and the parties concerning claims and demands, for disposing of the controversy through agreed settlement, for presenting proof at trial, for determining conflicting claims and ordering appropriate remedial action, for appeal and review, and for executing judgment and enforcing remedial measures. Policy criteria for appraising procedures may be sharpened in terms not only of efficiency in promoting particular values but also of certain overriding community goals, such as equal opportunity to a fair hearing, decision in accordance with the prescribed policies of the community, affording as much economy to all parties as is consistent with other values, affording maximum respect for human dignity with a minimum invasion of privacy or exercise of violence, securing a maximum effect on the enlightenment processes of the community and in ceremonializing the community values at stake, eliminating biased and prejudiced decision-makers, and encouraging a maximum use of scientific knowledge in ascertaining facts and shaping remedies.

Appraising. This is a detailed application of the more general intelligence function to continuing survey of the consequences of policy prescriptions and applications. Comparative investigation is not likely to reveal common occurrence.

Terminating. This is the function of putting an end to obsolete prescriptions of policy. Commonly the function is performed by new prescription. Special study of techniques for periodic revision and for resolving conflicts between prescriptions of differing times may, however, be useful.

With some such comprehensive framework of guiding theory, it might be possible for comparative study to rise to the challenge of contemporary need and make its contribution to the more perfect union of the free world and to the eventual organization of security and freedom throughout a perceful world community. Such a framework of theory would permit sufficiently precise description of the events to which decision-makers respond in terms of value changes which transcend the doctrinal peculiarities of particular nation-states. It also would require the investigation by all the techniques of modern science of how predispositional factors affecting decision, such as - character structure, class position, skills, and attitudes, vary from nation- 
state to nation-state and from context to context within nation-states. Hence it would make possible a meaningful survey through time of how different decision-makers, with their varying predispositions, appropriately located in different nation-states apply technical doctrines of varying degrees of equivalence to comparable problems to achieve identifiable effects on values.

The importance for policy, for the freedom and rationality of future decision, of the knowledge that might be so obtained is beyond present calculation. Communities might find, as individuals have found, that insightful knowledge of the past and clear prevision of future alternatives immeasurably increases potentialities. Though the universals it yields may ultimately be few, comparative study at its best might reveal the details of short-term, emerging relationships with unexpectedly high probability. ${ }^{64}$ Though it may never induce change in basic democratic values, such comparative study might also supply the continuing flow of knowledge by which specific operational interpretations can be given value goals and such goals be kept up to date. Enlargement of the context of community and power processes being observed can certainly be expected only to enlarge knowledge of expedients and alternatives and increase the possibilities of invention.

The hope that comparative study for policy purposes offers is, in sum, that of understanding the power and other value processes in which we live and of achieving the special insights necessary to effective cooperation and survival in the contemporary world. Denied the experimental method open to the physical sciences, applied legal science has no rational alternative to such study. Should the challenge outlined appear too formidable, it may be relevant to recall the principle, once invoked by a great comparative scholar," that "the standard of human performance is apt, though not sure, to rise in proportion to the magnitude of an undertaking."

64. The exposure of past rigidities in behavior may, it will perhaps bear emphasis, increase appreciation of opportunities for future change. The function of science in legal study is not so much that of predicting inevitabilities, as of stating the conditions of freedom.

65. The late Ernst Freund. Cf. Margaret Mead, The Comparative Study of Cullure and the Purposive Cultivation of Democratic Values in Conference on Scrence, PunLOSOPHY AND RELIGION 56, 65 (19+2): "Comparison of different cultures demonstrates that man may set his spiritual goal low or high. that he may cast himself a cheap or a heroic role, and that as he casts himself, so will he live and his children after him." 